\title{
PEMBERIAN REWARD PENGARUHNYA TERHADAP AKTIVITAS BELAJAR MAHASISWA PADA MATA KULIAH FISIKA DASAR
}

\author{
Effendi ${ }^{*}$ \\ Prodi Pendidikan Fisika STKIP Nurul Huda \\ Jalan Kotabaru Sukaraja, Buay Madang, OKU Timur, Sumatera Selatan \\ *E-mail: effendi@stkipnurulhuda.ac.id
}

\begin{abstract}
Abstrak
Reward merupakan salah satu faktor diluar dari pribadi mahasiswa. Dengan pemberian reward dalam proses perkuliahan secara tidak langsung akan membuat mahasiswa lebih bersemangat dan aktif sehingga terjadi proses pembelajaran yang efektif dan efisien. Permasalahan dalam penelitian ini adalah apakah pemberian reward berpengaruh terhadap aktivitas mahasiswa. Metode yang digunakan dalam penelitian ini adalah metode eksperimen. Populasidalam penelitian adalah seluruh seluruh mahasiswa yang mengambil mata kuliah fisika dasar. Variabel dalam penelitian ini ada dua, yaitu variabel bebas adalah pemberian reward, dan variabel terikat adalah aktivitas belajar mahasiswa. Pengumpulan data dilakukan dengan lembar observasi. Setelah data terkumpul, kemudian data dianalisis dengan ststistik uji-t dengan taraf signifikansi 5\%. Berdasarkan analisis data yang dilakukan didapat thitung $=6,20$ dan $\mathrm{t}_{\text {daftar }}=2,01$, hipotesis akan diterima apabila thitung terletak antara $-\mathrm{t}_{(1-1 / 2 \alpha)}<\mathrm{t}<\mathrm{t}_{(1-1 / 2 \alpha)}$. Dari hasil perhitungan dapat diketahui 6,20 tidak terletak antara $-2,01$ dan $+2,01$, sehingga kesimpulannya bahwa Ho ditolak dan Ha diterima yaitu terdapat pengaruh pemberian reward terhadap aktivitas belajar mahasiswa.
\end{abstract}

Kata kunci: reward, aktivitas belajar dan fisika dasar

\section{PENDAHULUAN}

Ada dua faktor yang mempengaruhi hasil belajar mahasiswa, yaitu faktor internal dan faktor eksternal (Ahmadi, 1998:72). Kedua faktor tersebut saling terkait antara satu dengan yang lain. Sehingga dengan demikian seoarang pendidik utama dosen harus mampu untuk memahami kedua faktor tersebut. Salah satu penyebab rendahnya hasil belajar mahasiswa terindikasi dari belum optimlanya seorang dosen dalam memperhatikan dua faktor itu, termasuk menggunakan media, metode dan strategi perkuliahan yang lebih variatif. Untuk itu, seorang dosen perlu mengembangkan pendekatan dan metode yang lebih variatif untuk mengatasi berbagai kesulitan mahasiswa seperti kejenuhan mempelajari fisika, kurangnya motivasi untuk belajar dan faktor lingkungan yang kurang mendukung proses pembelajaran. Maka, dosen harus mencari strategi yang cocok agar mahasiswa dapat tertarik dan lebih antusias untuk mengikuti perkuliahan di prodi pendidikan fisika. Salah satu hal yang dapat dilakukan yaitu dengan pemberian reward yang dapat diberikan pada saat kegiatan perkuliahan berlangsung.

Memberikan reward itu berarti sama dengan memberikan motivasi kepada mahasiswa sebagai salah satu faktor pencapaian prestasi akademiknya. Hal tersebut merupakan prakondisi yang harus ada pada diri seorang mahasiswa dalam usaha untuk motivasi dalam belajarnya. Adanya motivasi dapat mendorong mahasiswa untuk belajar selanjutnya berimplikasikan pada aktivitas belajar mahasiswa. Tujuan yang harus dicapai dalam pemberian reward adalah untuk lebih mengembangkan dan mengoptimalkan motivasi yang bersifat intrinsik dari motivasi ektrinsik, artinya mahasiswa melakukan suatu perbuatan, maka perbuatan itu timbul dari kesadaran mahasiswa itu sendiri. Pemberian reward juga diharapkan dapat membangun suatu hubungan yang positif antara dosen dan mahasiswa, karena reward itu adalah bagian 
dari pada penjelmaan dari rasa cinta kasih sayang seorang dosen kepada siswa.

Reward merupakan suatu bentuk teori penguatan positif yang bersumber dari teori behavioristik. Reward berasal dari Bahasa Inggris yang berarti penghargaan atau hadiah (John M. Echols dan Hasan Shadilya, 1996: 482). Pemberian reward dalam proses perkuliahan cukup penting terutama sebagai faktor eksternal dalam mempengaruhi dan mengarahkan perilaku mahasiswa. Hal ini berdasarkan atas berbagai pertimbangan logis, diantaranya pemberian reward ini dapat menimbulkan motivasi belajar mahasiswa dan dapat mempengaruhi perilaku positif dalam kehidupan mahasiswa.

Proses belajar yang dilakukan oleh mahasiswa merupakan kunci keberhasilan secara akademiknya. Proses belajar merupakan aktivitas psikis berkenaan dengan bahan belajar. Aktivitas belajar yang dialami oleh mahasiswa sebagai suatu proses, yaitu proses belajar mengajar (Dimyati, 2009: 236).

B. Diedrich, (dalam Sadirman 2010: 101) menggolongkan aktivitas belajar sebagai berikut :

1. Visual activies (kegiatan visual) seperti: membaca, mengamati demonstrasi, percobaan, mengamati gambar, melihat orang bekerja, dan lain-lain.

2. Oral activies (kegiatan oral) seperti: menyatakan, merumuskan, bertanya, memberi saran, mengeluarkan pendapat, mengadakan wawancara, diskusi dan lain-lain.

3. Listening activies (kegiatan mendengar) seperti: mendengarkan percakapan, uraian, diskusi, musik, pidato dan lain-lain.

4. Writing activies (kegiatan menulis) seperti: menulis cerita, mengarang, membuat laporan angket, menyalin dan lain-lain.

5. Drawing activies (kegiatan menggambar) seperti: menggambar, membuat grafik, peta, diagram dan lain-lain.

6. Mental activies (kegiatan mental) seperti: menanggapi, mengingat, memecahkan soal, menganalisis, melihat hubungan, mengambil keputusan.

7. Motor activies (kegiatan gerak) seperti: melakukan percobaan, membuat konstruksi, model mereparasi, bermain, berkebun, beternak dan lain-lain

8. Emosional activies (kegiatan emosional) seperti: menaruh minat, merasa bosan, gembira, bersemangat, bergairah, berani, tenang, gugup dan lain-lain.

Kurangnya aktivitas belajar merupakan salah satu faktor penyebab rendahnya penguasaan materi oleh siswa. Aktivitas belajar adalah rangkaian kegiatan fisik maupun mental yang dilakukan secara sadar oleh seseorang dan megakibatkan adanya perubahan dalam dirinya baik nampak maupun yang tidak nampak untuk diamati. Pengajaran yang efektif adalah pengajaran yang menyediakan kesempatan belajar sendiri atau melakukan aktivitas sendiri. mahasiswa belajar sambil bekerja. Dengan bekerja mereka memperoleh pengetahuan, pemahaman, dan aspek-aspek tingkah laku lainnya, serta mengembangkan keterampilan yang bermakna untuk hidup bermasyarakat (Hamalik, 2001: 171). Adapun tujuan dari penelitian ini secara umum yakni untuk mengetahui efektivitas pemberian reward terhadap hasil belajar mahasiswa prodi pendidikan fisika. Oleh karena itu nantinya hasil penelitian ini dapat bermanfaat dosen, mahasiswa dan peneliti.

\section{METODE/EKSPERIMEN}

Penelitian ini adalah penelitian yang bersifat kuantitatif. Penelitian kuantitatif adalah penelitian yang menggunakan teknik analisis statistik untuk mengukur data dan menarik kesimpulan. Jenis data penelitian merupakan komponen penelitian yang diperlukan oleh peneliti untuk memperoleh data dalam meneliti. Metode pengumpulan data yang digunakan dalam penelitian ini adalah metode observasi yang digunakan pada kelompok eksperimen dan kelompok kontrol pada saat proses pembelajaran sedang berlangsung. Sebelum 
lembar observasi digunakan untuk penelitian maka instrumen tersebut dipastikan dahulu kebaikan dan keburukannnya. Hasil ujicoba dianalisa untuk mengetahui apakah item-item lembar observasi tersebut memenuhi kualifikasi lembar observasi yang baik atau tidak. Lembar observasi aktivitas belajar mahasiswa dalam penelitian berjumlah 16 item

Data yang digunakan dalam penelitian ini adalah data kuantitatif. Dalam penelitian ini data yang digunakan meliputi data kontinum yang diperolah dari data data hasil belajar. Populasi dalam penelitian ini adalah seluruh mahasiswa pendidikan fisika yang mengambil mata kuliah fisika dasar yakni berjumlah 2 kelas. Teknik Pengumpulan data adalah teknik yang digunakan untuk memperoleh data sesuai dengan data yang diperlukan. dalam penelitian ini adalah menggunakan metode observasi. Sebelum digunakan dalam pengumpulan data, instrumen tersebut harus memenuhi kriteria instrumen yang baik. Sebelum analisis data dilakukan terlebih dahulu uji prasyarat yaitu uji normalitas dan uji homogenitas.

Pengujian noralitas dengan menggunakan rumus Kai Kuadrat $\left(\mathrm{X}^{2}\right)$ dan taraf kesalahan yang digunakan adalah $5 \%$ dengan dk (derajat kebebasan) $n-1$. Rumus Kai Kuadrat $\left(\mathrm{X}^{2}\right)$ sebagai berikut:

$$
x^{2}=\frac{(f o-f h)^{2}}{\mathrm{fh}}
$$

Sedangkan untuk melihat kedua sampel homogen atau tidak, maka homogenitas variansnya menggunakan uji F. Rumus statistik yang digunakan adalah:

$$
F_{\text {hit }}=\frac{\text { varians terbesar }}{\text { varians terkecil }}
$$

Dengan Kriteria uji tolak $\mathrm{H}_{0}$, jika : $F_{\text {hit }}$ $\geq F_{1 / 2} \alpha\left(V_{1}, V_{2}\right)$ dengan $\mathrm{F}_{1 / 2} \alpha\left(\mathrm{V}_{1}, \mathrm{~V}_{2}\right)$ didapat dari daftar I, dan terima $\mathrm{H}_{\circ}$ untuk harga $F_{\text {hit }}$ lainnya. Serta besarnya $\alpha$ diambil $5 \% V_{1}=n_{1}-1$ dan $V_{2}$ $=\mathrm{n}_{2}-1$ (Sudjana, $2005: 250$ ). Sedangkan untuk pengujian hipotesisnya menggunakan distribusi student. Untuk sampel random atau acak bebas, pengujian perbandingan mean dihitung dengan uji t sebagai berikut:

$$
\mathrm{thit}=\frac{X_{1}-X_{2}}{\sqrt[s g]{\frac{1}{n_{1}}+\frac{1}{n_{2}}}}
$$

Menggunakan taraf signifikan $5 \%$ dan $\mathrm{dk}$ $=n_{1}+n_{2}-2, \mathrm{t}$ hitung $\geq \mathrm{t}$ tabel maka $\mathrm{Ho}$ diterima dan Ho ditolak jika thitung mempunyai harga-harga lain (Sudjana, 2005:239).

\section{HASIL DAN PEMBAHASAN}

Pada analisis data hasil penelitian yang telah dilakukan, menunjukkan bahwa mahasiswa pada kelas eksperimen aktivitas belajarnya lebih baik jika dibandingkan dengan aktivitas belajar mahasiswa pada kelas kontrol. Hal ini terlihat jelas pada nilai rata-rata aktivitas belajarnya, dimana pada kelas eksperimen nilai rata- rata aktivitas belajarnya adalah $\overline{x_{e}}=$ 51,357 sedangkan pada kelas kontrol nilai ratarata aktivitas belajarnya adalah $\overline{x_{k}}=47,643$.

Adapun persentase dari aktivitas belajar fisika mahasiswa antara siswa yang dalam proses pembelajarannya ada pemberian reward dengan mahasiswa yang dalam proses pembelajarannya sama sekali tidak ada pemberian reward adalah seperti tabel 1 .

Tabel 1. Persentase aktivitas belajar

\begin{tabular}{ccccc}
\hline No & Skor & Kategori & \multicolumn{2}{c}{ Persentase (\%) } \\
\cline { 4 - 5 } & & & Kelas eksperimen & Kelas Kontrol \\
\hline $\mathbf{1}$ & $>54$ & Tinggi & 25 & 10,71 \\
$\mathbf{2}$ & $44-54$ & Sedang & 71,43 & 78,58 \\
$\mathbf{3}$ & $<44$ & Rendah & 3,57 & 10,71 \\
\hline \multicolumn{3}{c}{ Jumlah } & 100 & 100 \\
\hline
\end{tabular}


Dari tabel dapat dijelaskan bahwa mahasiswa yang mendapatkan skor > 54 pada kelas eksperimen $25 \%$ dan kelas kontrol $10,71 \%$. Ini menyatakan bahwa persentase pada kelas eksperimen untuk kategori aktivitas tinggi lebih besar dibandingkan pada kelas kontrol. Sedangkan skor < 44 pada kelas eksperimen $3,57 \%$ dan kelas yang kontrol $10,71 \%$. Ini menyatakan bahwa persentase pada kelas eksperimen untuk kategori aktivitas rendah lebih kecil dibandingkan kelas kontrol.

Analisis dan pembahasan di atas dapat ditarik kesimpulan bahwa ada pengaruh yang signifikan pemberian reward terhadap aktivitas belajar mahasiswa. Adanya pengaruh yang signifikan ini dapat dilihat melalui pengujian hipotesis, yang menghasilkan nilai $t$ hitung $>t$ tabel atau 6,20 > 2,01. Kriteria pengujian adalah terima Ho jika $-t_{1-1 / 2 \alpha}<t<t_{1-1 / 2 \alpha}$, dimana $t_{1-1 / 2 \alpha}$ didapat dari daftar distribusi $t$. Untuk harga t lainnya Ho ditolak. Pengujian hipotesis yang diterima adalah $\mathrm{Ha}$ dan $\mathrm{Ho}$ ditolak.

Hal ini berarti sesuai dengan pendapat Purwanto (2006: 182), yang menyatakan bahwa pemberian reward dalam suatu proses pembelajaran sangat dibutuhkan kebenarannya demi meningkatkan aktivitas belajar mahasiswa. Maksud dari pemberian reward kepada mahasiswa ini pada prinsipnya adalah agar setiap mahasiswa lebih giat lagi usahanya untuk memperbaiki atau mempertinggi prestasi akademik yang telah dicapainya, dengan kata lain mahasiswa menjadi lebih keras kemauannya untuk belajar lebih baik

\section{PENUTUP}

Terdapat pengaruh yang signifikan pemberian reward terhadap aktivitas mahasiswa. Hal ini dapat dilihat Pada kelas yang dalam proses pembelajarannya ada pemberian reward (kelas eksperimen) mahasiswa lebih aktif dalam mengikuti proses pembelajaran, hal ini dapat dilihat dari skor rata-rata aktivitas belajar mahasiswa yang diperoleh sebesar $\overline{x_{e}}=51,357$ yang termasuk dalam kategori skor tinggi, dengan skor maksimum 64. Pada kelas yang dalam proses pembelajarannya sama sekali tidak ada pemberian reward (kelas kontrol) mahasiswa cenderung pasif dalam mengikuti proses pembelajaran, hal ini dapat dilihat dari skor rata-rata aktivitas belajar siswa yang diperoleh sebesar $\overline{x_{k}}=47,643$ yang termasuk dalam kategori skor sedang, dengan skor maksimum 64. Aktivitas belajar mahasiswa yang baik terlihat pada kelas yang dalam proses pembelajarannya ada pemberian reward, yaitu ditunjukkan dari skor rata-rata aktivitas belajar mahasiswa yang diperoleh lebih besar jika dibandingkan dengan siswa yang dalam proses pembelajarannya sama sekali tidak ada pemberian reward. Dari hasil uji hipotesis yang dilakukan diperoleh nilai $t$ hitung $>t$ tabel atau $6,20>2,01$. Pengujian hipotesis yang diterima adalah $\mathrm{Ha}$ dan $\mathrm{Ho}$ ditolak.Jelas sekali bahwa apapun bentuknya reward secara psikologi pasti berdampak kepada pribadi seseorang terlebih kepada mahasiswa. Maka sudah seharusnya seorang dosen mampu memotivasi belajar mahasiswa sehingga berdampak kepada aktivitas perkulihannya yang akhirnya berdampak pula terhadap prestasi akademiknya.

\section{UCAPAN TERIMAKASIH}

Ucapan terimakasih kepada beberapa pihak yang telah membantu lancarnya kegiatan penelitian antara lain: 1) Ketua STKIP Nurul Huda Sukaraja, 2) Ketua prodi dan para dosen Prodi Pendidikan Fisika STKIP Nurul Huda Sukaraja, 3) Ketua Lembaga Penelitian dan Pengabdian Masyarakat (LP2M) STKIP Nurul Huda, 4) Seluruh mahasiswa pendidikan fisika yang mengambil mata kuliah fisika dasar.

\section{DAFTAR PUSTAKA}

Arikunto, Suharsimi. (2006). Prosedur Penelitian Suatu Pendekatan Praktik. Jakarta: $\quad$ PT. Rineka Cipta.

(2010). Prosedur Penelitian suatu Pendekatan Praktek. Jakarta: PT. Rineka Cipta.

A.M, Sardiman. (2010). Interaksi dan Motivasi 
Belajar Mengajar. Jakarta:PT. Raja Grasindo Persada.

Budiningsih, Asri. (2004). Belajar dan

Pembelajaran. Jakarta : PT.

Rineka Cipta.

Dimyati, Mujiono. (2009). Belajar dan Pembelajaran. Jakarta : PT. Rineka Cipta.

Departemen Agama RI. (2002). Al-quran

Terjemah dan Penjelasan Ayat

Ahkam. Jakarta : Pena.

Echol, John M., Shadily, Hasan. (1996). Kamus Inggris Indonesia. Jakarta : Gramedia.

Hamalik, Oemar. (2001). Proses Belajar Mengajar. Jakarta : Bumi Aksara.

Siregar, S. (2010). Statistika Deskriptif untuk Penelitian. Jakarta:Raja Grafindo Persada.

Slameto, (2003). Belajar Dan Faktor Yang Mempengaruhinya. Jakarta: Renika Cipta.

Sudjana. (2005). Metoda Statistika. Bandung : Tarsito.

Sugiyono. (2008). Metode Penelitian Pendidikan. Bandung : Alfabeta.

Sukmadinata, NS. 2001. Metode Penelitian Pendidikan. Bandung: Remaja Rosdakarya. 